CORRECTION

\title{
Correction: Adverse clinical outcomes in people at clinical high-risk for psychosis related to altered interactions between hippocampal activity and glutamatergic function
}

Paul Allen, Emily J. Hird (D), Natasza Orlov, Gemma Modinos (D), Matthijs Bossong, Mathilde Antoniades, Carly Sampson, Matilda Azis, Oliver Howes, James Stone, Jesus Perez, Matthew Broome, Anthony A. Grace and Philip McGuire

(c) The Author(s) 2021

Translational Psychiatry (2021)11:607; https://doi.org/10.1038/s41398-021-01731-x

Correction to: Translational Psychiatry https://doi.org/10.1038/ s41398-021-01705-z, published online 10 November 2021

The original version of this article unfortunately contained a spelling mistake in the name of Anthony A. Grace. The authors apologize for the error. The original article has been corrected.

\begin{abstract}
(1) Open Access This article is licensed under a Creative Commons Attribution 4.0 International License, which permits use, sharing, adaptation, distribution and reproduction in any medium or format, as long as you give appropriate credit to the original author(s) and the source, provide a link to the Creative Commons license, and indicate if changes were made. The images or other third party material in this article are included in the article's Creative Commons license, unless indicated otherwise in a credit line to the material. If material is not included in the article's Creative Commons license and your intended use is not permitted by statutory regulation or exceeds the permitted use, you will need to obtain permission directly from the copyright holder. To view a copy of this license, visit http://creativecommons. org/licenses/by/4.0/.
\end{abstract}

(๑) The Author(s) 2021 